\title{
Growth Attributes and Pod Yield of Four Cowpea (Vigna unguiculata (L.) Walp.) Varieties as Influenced by Residual Effect of Different Application Rates of Farmyard Manure
}

\author{
B.A Babaji (Corresponding Author), R. A. Yahaya \& M.A. Mahadi \\ Department of Agronomy, Ahmadu Bello University, Zaria, Nigeria \\ E-mail: bash866@yahoo.com
}

M.M. Jaliya

National Agricultural Extension Research and Liaison Services, A. B. U., Zaria, Nigeria

A.I. Sharifai, H.N. Kura \& U.L. Arunah

Department of Agronomy, Ahmadu Bello University, Zaria, Nigeria

A. Ibrahim

National Agricultural Extension Research and Liaison Services, A. B. U., Zaria, Nigeria

H. Ajeigbe

International Institute of Tropical agriculture, Kano Sub-station, Nigeria

Received: October 8, 2010 Accepted: November 2, $2010 \quad$ doi:10.5539/jas.v3n2p165

\begin{abstract}
Field trials were conducted in 2005 and 2006 rainfed conditions at the Institute for Agricultural Research farm, Samaru to test the pod yield response of four cowpea(Vigna unguiculata (L) Walp) varieties (IT93K-452-1, IT90K-82-2, IT97K-499-35 and IT96D-757) under four rates of residual farmyard manure, FYM $(0,5,10$ and $15 \mathrm{t} \mathrm{FYM} \mathrm{ha}^{-1}$ ) using split plot design and three replication. Residual FYM significantly enhanced soil chemical composition. Taller plants with longer pods were observed in plots supplied with $10 \mathrm{t} \mathrm{FYM} \mathrm{ha}^{-1}$. Plots supplied with lower rate of $5 \mathrm{t} \mathrm{FYM} \mathrm{ha}{ }^{-1}$ had plants with more leaves and branches and higher pod yield. Variety IT93K-452-1 and IT97K-499-35 were taller while IT93K-4542-1 flowered and matured earlier. Bigger pods were produced by IT90K-82-2 and IT96D-757. IT97K-499-35 had the highest pod yield. IT93K-452-1 exhibited the least growth. IT97K-499-55 grown in plot supplied with $5 \mathrm{t} \mathrm{FYM} \mathrm{ha}^{-1} \mathrm{t}$ produced the highest pod yield ha ${ }^{-1}$.
\end{abstract}

Keywords: Growth attributes, Residual FYM, Cowpea, Variety

\section{Introduction}

Nigeria is the world's largest producer of cowpea (Vigna unguiculata (L.) Walp.) and the crop supplies $40 \%$ of the daily protein intake of its ever increasing population, thereby supplementing the low protein menus due to high cost of animal source of protein (Miko and Mohammed 2007a and 2007b). Cowpea production like most other crops is limited by factors such as poor yielding varieties and nutrition, absence of right strain of rhizobia, pests, and diseases among other factors of production (Agboola, 1978; Chiezey et. al., 1990; Kan'ankuk'a, 1999). It is generally believed by most cowpea growers in the country that the productions of legumes like cowpea do not require inputs like organic and inorganic fertilizers (Kan'ankuk'a, 1999). This is due to the excessive vegetation at expense of grain production of this crop under fertilized fields.

Cowpea can fix about $40 \mathrm{kgN} / \mathrm{ha}$ from nodules in the presence of right rhizobia strain of, which can satisfy the crop nitrogen $(\mathrm{N})$ requirements (Singh, 1997). There are some reports indicating that in poor soils, cowpea hardly satisfies $\mathrm{N}$ requirements but the crop performance is improved by fertilizing (Chiezey et. al., 1990; 
Kan'ankuk'a, 1999; FAO, 2005; FAO, 2006b). Fertilizers of organic source are known to enhance macro and micronutrients, water holding capacity, $\mathrm{pH}$ and soil structure (Lekasi et. al., 2001; FAO, 2006a; FAO, 2006b). The development of high yielding cowpea genotypes by research institutes is highly desirable to encourage farmers to shift toward monoculture system, since they grow cowpea mostly as cash crop (Singh, 1997 and 1998). Farmers are also known to rely on podded cowpea as source of food particularly during time of food scarcity which coincides with the peak period of the production period. Based on this, the present study was undertaken with the aim of a) to determine the most pod producing cowpea variety and b) to determine the best response of the cowpea varieties to residual FYM

\section{Materials and Methods}

Two field experiment were conducted during the rainy season of 2005 and 2006 at the Institute for Agricultural Research Farm, Samaru (1 $11^{0} 11^{\prime} \mathrm{N}, 0738^{\prime} \mathrm{E}, 686 \mathrm{~m}$ above the sea level) to evaluate the pod yield response of four cowpea varieties to residual farmyard manure (FYM). The source of the FYM used is sheep manure. The experiment is a follow up to another one conducted in 2004 and 2005 rainy seasons each on a different plot to evaluate the response of chilli pepper (Capsicum frutescens L.) supplied with four rates of farmyard manure $(0,5$, 10 and 15 tonnes FYM ha ${ }^{-1}$ ). In 2005 and 2006 year four cowpea varieties (IT93K-452-1, IT90K-82-2, IT97K-499-35 and IT96D-757) were sown in rotation to chilly pepper grown the previous respective rainy seasons of 2004 and 2005. These cowpea varieties were randomly allocated main block of the FYM that occupied sub-plots the previous rainy season of 2004 and 2005. Split plot arrangement was employed with three replicates. Random samples of soils to a depth of $30 \mathrm{~cm}$ were taken prior to sowing in each season and subplot and later bulked as per FYM treatment and analysed for physico-chemical properties. The gross sub-plot and net plot sizes (length $\mathrm{x}$ breath) were $3 \times 3 \mathrm{~m}\left(9 \mathrm{~m}^{2}\right)$ and $1.5 \times 2 \mathrm{~m}\left(3 \mathrm{~m}^{2}\right)$, respectively. Each main plot has size of $3 \mathrm{x}$ $14.75 \mathrm{~m}\left(42.75 \mathrm{~m}^{2}\right)$.

The cowpea varieties used were extra early (IT93K-452-1), early maturing (IT90K-82-2 and IT97K-499-35) and medium maturing (IT96D-757). The land was sprayed 2 weeks to sowing with $21 /$ ha of roundup or glyphosate (360 Isopropylamine salt) herbicide which helped to control weeds. Seeds were sown at $25 \mathrm{~cm}$ apart within row and $75 \mathrm{~cm}$ between ridges. The crop was sown on July $17^{\text {th }} 2005$ and 2006 . Weeds that later emerged were controlled manually at 3 weeks after sowing (WAS) and earthed up at 5 WAS.

Data collected include plant height, numbers of leaves, and branches per plant at 3, 6 and 9 WAS, days to $50 \%$ flowering and maturity, pod length and pod yield/ha at harvest. All the crop data collected were statistically analysed and where the F-values were found to be significant, the treatment means were separated using Duncan's multiple range test (Duncan, 1955).

\section{Results}

Table 1 shows the effect of rates of previous season applied FYM on height of four varieties of cowpea at 3, 6 and 9 WAS of 2005 and 2006 rainy seasons. Heights of the four varieties at 3 WAS of 2006 were significantly similar. At 3 and 9 WAS of 2005 IT90K-82-2 and IT96D-757 were tallest though significantly at par with that of IT93K-452-1 only at 3 WAS of 2005. During the $6^{\text {th }}$ week of both seasons and $9^{\text {th }}$ week of 2006 IT93K-452-1 and IT97K-499-35 were tallest. The response of height to rates of residual FYM was not significant at 3 and 6 WAS of 2006. Increasing FYM from 0-5t/ha significantly increased height only at 6 and 9 WAS of 2005, and further increase to $10 \mathrm{t} / \mathrm{ha}$ had enhanced height; beyond 10t/ha height did not increase significantly.

Number of leaves of cowpea as influenced by variety and rates of previous season applied FYM at various sampling periods of 2005 and 2006 rainy seasons is presented in Table 2. The varieties tested had varied leaf number only at 3 and 6 WAS of 2005 and 6 WAS of 2006 season. Varieties IT93-452-1, IT90K-82-2 and IT97K-499-35 recorded similar but significantly lower leaf number than IT96D-757 at 3 WAS of 2005. However, during the mid growth stage of 6 WAS, IT93K-452-1 had the least number of leaves which did not differ from that of IT97K-499-35 only in 2005.

Residuals farm yard manure had influenced the production of cowpea leaves. Leaf production reached its maximum at $15 \mathrm{t} / \mathrm{ha}$ at all the sampling periods of 2005 , even though the values so far obtained did not differ significantly from that of the next lower rate of $10 \mathrm{t} / \mathrm{ha}$ at 3 and 9 WAS. During the following season all the applied FYM rates had statistically similar but more leaves than the control. The effect of factor interaction on this parameter was not significant.

The response of number of branches of cowpea to variety and residual manure is shown on Table 3 . It was observed that varieties had similar branch number only at 6 WAS of 2006. The response however was inconsistent among the other sampling periods of both seasons. At the early sampling period of 3 WAS of the 
two seasons IT96D-757 had more branches than other three varieties in 2005 an only IT97K-499-35 in 2006. At 6 WAS of 2005 branches produced by IT90K-82-2 was significantly more than for IT93k-452-1 and IT96D-757 only. During the last sampling period of 9 WAS of 2005, the highest and least branching varieties are IT93K-452-1 and IT96D-757, respectively. The situation was reversed in the following year.

Increasing FYM rate from 0 to $5 \mathrm{t} / \mathrm{ha}$ significantly enhanced branching in cowpea; further increase to $10 \mathrm{t} / \mathrm{ha}$ had raised branch number significantly at 6 WAS of 2006 and 9 WAS of both seasons. Beyond this rate branching remained significantly unaffected. The differences in branching between 0 and $15 \mathrm{t} \mathrm{FYM/ha}$ at $3 \mathrm{WAS}$ of 2005 and 5 and $15 \mathrm{t} \mathrm{FYM/ha}$ at $9 \mathrm{WAS}$ of 2006 were not significant. The effect of factor interaction on this parameter was not significant.

The interaction of variety and residual FYM was only significant on branching at 3 WAS (Table 4). Only variety IT96D-757 significantly responded to previous year applied FYM and recorded the highest branch number at 10 $\mathrm{t}$ FYM/ha that was more than for control only.

Response of days to $50 \%$ flowering and maturity is shown on Table 5 . The response was significant only in 2005 . In 2005, IT93k-452-1 was earliest while IT90K-82-2 and IT96D-757 flowered and reached maturity 1 and 2 weeks later, respectively. The response of these parameters to residual manure was not significant. The effect of factor interaction on this parameter was not significant.

Pod length and pod yield/ha as influenced by variety and residual FYM is presented on Table 6. Variety IT90K-82-2 and IT96D-757 had similar and longer pods only than IT93K-452-2 and IT97K-499-35 in 2005 and IT93K-452-1 in 2006. Increasing FYM rate from $0-5$ and further to $10 \mathrm{t} / \mathrm{ha}$ enhanced this parameter; beyond this rate pod length remained unaffected. The effect of factor interaction on this parameter was not significant.

IT97K-499-35 consistently produced the highest pod yield/ha while IT96D-757 in 2005 and other varieties in 2006 had the least. Control significantly recorded lower pod yield only than the three applied residual FYM rates. The effect of factor interaction on this parameter was not significant.

\section{Discussion}

Generally the result of this studies have shown better crop performance in terms of vegetative production and pod yield in 2006 than in 2005 . The reason could be attributed to higher rainfall $(526.9 \mathrm{~mm}$ in 2005 and $757.7 \mathrm{~mm}$ in 2006) and milder temperature $\left(13.6-34.4^{\circ} \mathrm{C}\right.$ in 2005 and $12-32^{\circ} \mathrm{C}$ in 2006) experienced during the production season of 2006 rainfed condition (see appendix I). Variety IT93K-452-1 was observed to be low yielding as a result of production of fewer numbers of leaf and branch. Production of more leaves and branches means higher light interception and more photo-assimilate production that increase yield. Another reason for low yield by IT93K-452-1 could be due to its early maturity period. Longer leaf duration also plays a crucial role in increasing crops yields. Early maturing crop varieties are believed to be low yielding due to shorter green leaf duration (Babaji et al., 2010; Singh, 1997 and (1998); Miko and Mohammed, 2007a and 2007b.

Taller and more branching cowpeas were observed in plot previously supplied with 5 tFYM ha ${ }^{-1}$ during the early sampling period. However, as the crop developed older the demand for environmental resources increased, hence, the reason for taller plants with more branch reached at $10 \mathrm{tFYM} \mathrm{ha}^{-1}$. Number of leaves was mostly higher in plot supplied with $5 \mathrm{tFYM} \mathrm{ha}{ }^{-1}$ the previous year, indicating variation in response of these important growth parameters to environmental resources. In general, the positive response of the above ground plant parts to graded levels of previously applied FYM could be as a result of the role play by organic manure in enhancing plant nutrients since soil testing of the experimental plot have shown the control plot having lower nutrient content. Likewise, organic manure are also known to supplied soils with both macro and micronutrients, increase water holding capacity and good crops as well help in the control of pests and diseases (FAO, 2007b).

Pod length and yield were observed that positively respond to previous applied FYM with there respective high values attained at 10 and $5 \mathrm{tFYM} \mathrm{ha}^{-1}$, respectively. This indicates that higher values of these important cowpea attributes are met at this respective FYM rates. Pod yield produced in plots supplied with 5 tFYM ha ${ }^{-1}$ the previous rainy season were 25 and 127 percent more than for the control in 2005 and 2006, respectively. The positive response recorded could be as a result of better growth achieved at these rates. This is because higher vegetative production in crop means higher interception of light and therefore more assimilate production that increase yield. Reports by FAO (2007a and 2007b) have shown that nutrients supplied previous crop affects the performance of the following crop. Therefore they further stressed that fertilizer use means matching the supply of nutrients to those require by crops. Likewise, Babaji et al. (2010) and Rutunga and Neel (2006) have further showed the long lasting effect of soil applied organic manure in sustaining crop yield when compared with mineral fertilizer. 
In conclusion, three of the varieties generally exhibited better growth than IT93K-452-1 while IT97K-499-55 and growing of cowpea on plots supplied with FYM at $5 \mathrm{tha}^{-1}$ the previous year produced the highest pod yield $h \mathrm{a}^{-1}$.

\section{References}

Anon, (2007a). Effect of organic and inorganic nutrient sources on soil mineral nitrogen and maize yield in Western Kenya. [Online] Available: www.ciat.cgiar.org.

Anon, (2007b). Managing soil fertility for vegetable production. [Online] Available: www.ciat.cgiar.org.

Agboola, A.A. (1978). Influence of soil organic matter on cowpea response to nitrogen fertilizer. Agronomy Journal, 70(1):25-28.

Babaji, Bashir A, Rilwanu A. Yahaya, Musa A. Mahadi, Muhammad M. Jaliya, Hakeem A.Ajeigbe, Aminu I. Sharifai, Habu N. Kura, Othman L. Arunah \& Ahmed Ibrahim. (2010). Response of cowpea [Vigna unguiculata (L) Walp] to residual effect of different application rates of sheep manure on chilli pepper (Capsicum annuum). Journal of Food, Agriculture \& Environment, Vol. 8 (2): 339 - 343 WFLPublisher.

Chiezey, U.F, Katung, P.D \& Yayock, J.Y. (1990). Response of cowpea (V. unguiculata (L.) Walp.), var. sampea-7 to nitrogen and phosphorus following a maize crop. Samaru Journal of Agricultural Education, 4|(1): 161-168.

Duncan, D.B. (1955). Multiple ranges and multiple F-test. Biometrics, 11: 1- 42.

FAO. (2007). Food and Agricultural Organization of the United Nation Crop Production statistics for West Africa. [Online] Available: http://faostat.fao.or/site/567/default.aspc.

FAO. (2005). Fertilizer use by crop in Ghana. Land an plant nutrition management service: Land and water development division. Food and Agriculture Organization of the United Nations, Rome. 40pp.

FAO. (2006a). Improving plant nutrient management for better farmer livelihoods, food security and environmental sustainability. Proceedings of a Regional Workshop Beijing, China 12-16 December 2005. Food and Agriculture Organization of the United Nations Regional office for Asia and Pacific, Bankok. 125pp.

FAO. (2007b). Fertilizer use by crop in Zimbabwe. Land and plant nutrition management service: Land and water development division. Food and Agriculture Organization of the United Nations, Rome. 55pp.

Kan'ankuk'a, C.N. (1999). Effect of lime, $\mathrm{N}$ and $\mathrm{P}$ on growth, yield and yield components of cowpea ( $V$. unguiculata (L.) Walp.). Thesis submitted to the Postgraduate school, Ahmadu Bello University, Zaria. 110pp.

Lekasi, J.K., Tanner, J.C., Kimani, S.K. \& Harris, P.J.C. (2001). Manure management in the Kenya Highlands :Practices and Potential, $2^{\text {nd }}$ ed. High potential production system portfolio of the natural resources, knowledge strategy, Department for International Development. 41pp.

Miko, S. \& Mohammed, I.B. (2007a). Performance of improved cowpea genotypes in the Sudan Savanna: I. Growth and dry matter production. Biological and Environmental Sciences Journal for the Tropics, 4(1):12-18.

Miko, S. \& Mohammed, I.B. (2007b). Performance of improved cowpea genotypes in the Sciences Journal Sudan Savanna:I1. Yield and yield components. Biological and Environmental Sciences Journal for the Tropics. 4(1):12-18.

Singh, B.B. (1997). Performance of promising cowpea varieties at Minjibir pp14-15. IITA, Annual report 1997. Project II Cowpea Cereals Systems Improvement in the Savanna.

Singh, B.B. (1998). Performance of promising cowpea varieties at Minjibir. Pp.14-15. IITA, Annual Report 1999. Project II Cowpea Cereals Systems Improvement in the Savanna. 
Appendix I. Meteorological data showing mean showing mean rainfall, temperature and relative humidity of the experimental area during 2005 and 2006 under rainfed condition

\begin{tabular}{|c|c|c|c|c|}
\hline & \multirow[t]{2}{*}{ Rainfal (mm) } & \multicolumn{2}{|c|}{ Temperature $\left({ }^{\circ} \mathrm{C}\right)$} & \multirow[t]{2}{*}{ Relative humidity (\%) } \\
\hline & & Minimum & Maximum & \\
\hline \multicolumn{5}{|l|}{ Month } \\
\hline \multicolumn{5}{|c|}{$\underline{2005}$} \\
\hline July & 152.6 & 20.9 & 30.2 & 83.0 \\
\hline August & 235.5 & 20.1 & 29.2 & 87.7 \\
\hline September & 122.4 & 20.3 & 31.7 & 74.9 \\
\hline October & 16.4 & 18.5 & 33.2 & 57.1 \\
\hline November & NA & 14.1 & 34.4 & 24.0 \\
\hline December & NA & 13.6 & 33.2 & 16.8 \\
\hline \multicolumn{5}{|c|}{$\underline{2006}$} \\
\hline July & 232.2 & 21.0 & 31.0 & 78.3 \\
\hline August & 222.0 & 20.0 & 30.0 & 82.0 \\
\hline September & 275.0 & 20.1 & 30.9 & 80.4 \\
\hline October & 28.5 & 20.0 & 32.0 & 66.5 \\
\hline November & NA & 13.5 & 31.2 & 22.0 \\
\hline December & NA & 12.0 & 30.4 & 18.2 \\
\hline
\end{tabular}

Table 1. Effect of rate of previous year applied FYM on the mean height $(\mathrm{cm})$ per plant of four varieties of cowpea at Samaru during 2005 and 2006 under rainfed condition

\begin{tabular}{|l|l|l|l|l|l|l|}
\hline & \multicolumn{5}{|c|}{ Plant height (cm) } \\
\hline Treatment & \multicolumn{2}{|c|}{3 WAS } & \multicolumn{2}{|c|}{ 6WAS } & \multicolumn{2}{|c|}{ 9WAS } \\
\hline Varieties & 2005 & 2006 & 2005 & 2006 & 2005 & 2006 \\
\hline IT93K-452-1 & & & & & & \\
IT90K-82-2 & $27.8 \mathrm{a}$ & $29.9 \mathrm{a}$ & $61.8 \mathrm{a}$ & $30.3 \mathrm{ab}$ & $69.9 \mathrm{~b}$ & $101.3 \mathrm{a}$ \\
IT97K-499-35 & $26.9 \mathrm{a}$ & $28.7 \mathrm{a}$ & $48.8 \mathrm{~b}$ & $27.8 \mathrm{bc}$ & $78.8 \mathrm{a}$ & $41.6 \mathrm{~b}$ \\
IT96D-757 & $25.0 \mathrm{~b}$ & $26.5 \mathrm{a}$ & $62.3 \mathrm{a}$ & $33.9 \mathrm{a}$ & $72.5 \mathrm{~b}$ & $90.4 \mathrm{a}$ \\
& $27.8 \mathrm{a}$ & $28.3 \mathrm{a}$ & $46.1 \mathrm{~b}$ & $25.3 \mathrm{c}$ & $80.0 \mathrm{a}$ & $42.6 \mathrm{~b}$ \\
FYM (t/ha) applied the previous year & & & & & & \\
0 & & & & & & \\
5 & $23.8 \mathrm{~b}$ & $27.8 \mathrm{a}$ & $40.5 \mathrm{c}$ & $26.7 \mathrm{a}$ & $63.3 \mathrm{c}$ & $64.5 \mathrm{a}$ \\
10 & $27.5 \mathrm{a}$ & $29.3 \mathrm{a}$ & $51.1 \mathrm{~b}$ & $29.9 \mathrm{a}$ & $74.4 \mathrm{~b}$ & $67.8 \mathrm{a}$ \\
15 & $27.6 \mathrm{a}$ & $28.2 \mathrm{a}$ & $65.3 \mathrm{a}$ & $29.4 \mathrm{a}$ & $82.7 \mathrm{a}$ & $74.2 \mathrm{a}$ \\
& $28.7 \mathrm{a}$ & $28.1 \mathrm{a}$ & $62.1 \mathrm{a}$ & $31.5 \mathrm{a}$ & $80.8 \mathrm{a}$ & $69.4 \mathrm{a}$ \\
Interaction & & & & & & \\
V x M & & & & & & \\
\hline
\end{tabular}

Means followed by the same letter(s) within a treatment group and column are not statistically significant using DMRT $(\mathrm{P}=0.05), \mathrm{NS}=$ Not significant $(\mathrm{P}=0.05), \mathrm{FYM}=$ Farmyard manure, $\mathrm{V}=$ Varieties, $\mathrm{M}=\mathrm{FYM}$ applied the previous year 
Table 2. Effect of rate of previous year applied FYM on the mean number of leaves per plant of four varieties of cowpea at Samaru during 2005 and 2006 under rainfed condition

\begin{tabular}{|l|c|c|c|c|c|c|}
\hline & \multicolumn{5}{|c|}{ Number of leaves per plant } \\
\hline Treatment & \multicolumn{2}{|c|}{3 WAS } & \multicolumn{2}{c|}{6 WAS } & \multicolumn{2}{|c|}{9 WAS } \\
\hline Varieties & 2005 & 2006 & 2005 & 2006 & 2005 & 2006 \\
IT93K-452-1 & & & & & & \\
IT90K-82-2 & $3.3 \mathrm{~b}$ & $5.5 \mathrm{a}$ & $30.1 \mathrm{~b}$ & $64.8 \mathrm{~b}$ & $45.6 \mathrm{a}$ & $81.2 \mathrm{a}$ \\
IT97K-499-35 & $3.3 \mathrm{~b}$ & $5.9 \mathrm{a}$ & $35.7 \mathrm{a}$ & $95.2 \mathrm{a}$ & $43.0 \mathrm{a}$ & $74.7 \mathrm{a}$ \\
IT96D-757 & $3.4 \mathrm{~b}$ & $5.6 \mathrm{a}$ & $33 . \mathrm{ab}$ & $89.1 \mathrm{a}$ & $43.2 \mathrm{a}$ & $68.6 \mathrm{a}$ \\
& $4.0 \mathrm{a}$ & $6.3 \mathrm{a}$ & $37.3 \mathrm{a}$ & $90.8 \mathrm{a}$ & $44.0 \mathrm{a}$ & $83.9 \mathrm{a}$ \\
FYM (t/ha) applied the previous year & & & & & & \\
0 & & & & & & \\
5 & $2.8 \mathrm{c}$ & $4.5 \mathrm{~b}$ & $22.4 \mathrm{~d}$ & $61.8 \mathrm{~b}$ & $32.8 \mathrm{c}$ & $50.7 \mathrm{~b}$ \\
10 & $3.5 \mathrm{~b}$ & $6.1 \mathrm{a}$ & $33.2 \mathrm{c}$ & $85.0 \mathrm{a}$ & $42.6 \mathrm{~b}$ & $79.8 \mathrm{a}$ \\
15 & $3.8 \mathrm{ab}$ & $6.5 \mathrm{a}$ & $38.5 \mathrm{~b}$ & $96.2 \mathrm{a}$ & $49.1 \mathrm{a}$ & $88.6 \mathrm{a}$ \\
& $3.9 \mathrm{a}$ & $6.2 \mathrm{a}$ & $42.5 \mathrm{a}$ & $97.0 \mathrm{a}$ & $51.3 \mathrm{a}$ & $89.3 \mathrm{a}$ \\
Interaction & & & & & & \\
V x M & NS & NS & NS & NS & NS & NS \\
\hline
\end{tabular}

Means followed by the same letter(s) within a treatment group and column are not statistically significant using DMRT $(\mathrm{P}=0.05), \mathrm{NS}=$ Not significant $(\mathrm{P}=0.05), \mathrm{FYM}=$ Farmyard manure, $\mathrm{V}=$ Varieties, $\mathrm{M}=\mathrm{FYM}$ applied the previous year.

Table 3. Effect of rate of previous year applied FYM on the mean number of branches per plant of four varieties of cowpea at Samaru during 2005 and 2006 under rainfed condition

\begin{tabular}{|l|l|l|l|l|l|l|}
\hline & \multicolumn{7}{|c|}{ Number of branches per plant } \\
\hline & 2005 & 2006 & 2005 & 2006 & 2005 & 2006 \\
\hline Treatment & 3 WAS & 3 WAS & 6 WAS & 6 WAS & 9 WAS & 9 WAS \\
\hline Varieties & & & & & & \\
IT93K-452-1 & $1.2 \mathrm{~b}$ & $2.3 \mathrm{a}$ & $5.1 \mathrm{c}$ & $10.5 \mathrm{a}$ & $8.5 \mathrm{a}$ & $12.3 \mathrm{c}$ \\
IT90K-82-2 & $1.0 \mathrm{~b}$ & $2.1 \mathrm{a}$ & $6.2 \mathrm{a}$ & $10.7 \mathrm{a}$ & $7.3 \mathrm{~b}$ & $13.2 \mathrm{~b}$ \\
IT97K-499-35 & $1.0 \mathrm{~b}$ & $1.1 \mathrm{~b}$ & $5.9 \mathrm{ab}$ & $10.4 \mathrm{a}$ & $7.2 \mathrm{~b}$ & $12.7 \mathrm{~b}$ \\
IT96D-757 & $1.6 \mathrm{a}$ & $2.2 \mathrm{a}$ & $5.4 \mathrm{bc}$ & $11.5 \mathrm{a}$ & $5.8 \mathrm{c}$ & $15.1 \mathrm{a}$ \\
& & & & & & \\
FYM (t/ha) applied the previous year & & & & & & \\
0 & & & & & & \\
5 & $1.0 \mathrm{~b}$ & $1.2 \mathrm{~b}$ & $4.3 \mathrm{~b}$ & $5.3 \mathrm{c}$ & $5.3 \mathrm{c}$ & $10.1 \mathrm{c}$ \\
10 & $1.3 \mathrm{a}$ & $1.9 \mathrm{a}$ & $5.9 \mathrm{a}$ & $10.8 \mathrm{~b}$ & $6.8 \mathrm{~b}$ & $13.2 \mathrm{~b}$ \\
15 & $1.3 \mathrm{a}$ & $2.2 \mathrm{a}$ & $6.0 \mathrm{a}$ & $13.9 \mathrm{a}$ & $7.9 \mathrm{ab}$ & $15.8 \mathrm{a}$ \\
& $1.2 \mathrm{ab}$ & $2.3 \mathrm{a}$ & $6.3 \mathrm{a}$ & $13.1 \mathrm{a}$ & $8.8 \mathrm{a}$ & $14.2 \mathrm{ab}$ \\
Interaction & & & & & & \\
V x M & $*$ & NS & NS & NS & NS & NS \\
\hline
\end{tabular}

Means followed by the same letter(s) within a treatment group and column are not statistically significant using DMRT $(\mathrm{P}=0.05), *$ Significant $(\mathrm{P}=0.05), \mathrm{NS}=$ Not significant $(\mathrm{P}=0.05), \mathrm{FYM}=$ Farmyard manure, $\mathrm{V}=$ Varieties, $\mathrm{M}=\mathrm{FYM}$ applied the previous year. 
Table 4. Variety and rate of previous year applied FYM interaction on the mean number of branches at 3 WAS of 2005 under rainfed condition

\begin{tabular}{|l|l|l|l|l|}
\hline Treatments & \multicolumn{4}{|l|}{ FYM (t/ha) applied the previous year } \\
\hline & 0 & 5 & 10 & 15 \\
\hline Varieties & & & & \\
IT93K-452-1 & $1.0 \mathrm{c}$ & $1.2 \mathrm{bc}$ & $1.2 \mathrm{bc}$ & $1.5 \mathrm{abc}$ \\
IT90K-82-2 & $1.0 \mathrm{c}$ & $1.0 \mathrm{c}$ & $1.0 \mathrm{c}$ & $1.5 \mathrm{abc}$ \\
IT97K-499-35 & $1.0 \mathrm{c}$ & $1.0 \mathrm{c}$ & $1.0 \mathrm{c}$ & $1.0 \mathrm{c}$ \\
IT96D-757 & $1.0 \mathrm{c}$ & $2.0 \mathrm{ab}$ & $2.1 \mathrm{a}$ & $1.3 \mathrm{abc}$ \\
SE+ $=0.28$ & & & & \\
\hline
\end{tabular}

Means followed by the same letter(s) within a set of interaction means are not statistically significant using DMRT $(\mathrm{P}=0.05), \mathrm{FYM}=$ Farmyard manure,

Table 5. Effect of rate of previous year applied FYM on the mean days to $50 \%$ flowering and maturity of four varieties of cowpea at Samaru during 2005 and 2006 under rainfed condition

\begin{tabular}{|l|l|l|l|l|}
\hline Treatments & Days to 50\% flowering & \multicolumn{3}{c|}{ Days to 50\% maturity } \\
\hline & 2005 & 2006 & 2005 & 2006 \\
\hline Varieties & & & & \\
IT93K-452-1 & $42.8 \mathrm{c}$ & $18.7 \mathrm{a}$ & $60.6 \mathrm{c}$ & $61.0 \mathrm{a}$ \\
IT90K-82-2 & $50.2 \mathrm{a}$ & $20.1 \mathrm{a}$ & $73.8 \mathrm{a}$ & $60.8 \mathrm{a}$ \\
IT97K-499-35 & $45.7 \mathrm{~b}$ & $22.0 \mathrm{a}$ & $63.1 \mathrm{~b}$ & $57.7 \mathrm{a}$ \\
IT96D-757 & $50.2 \mathrm{a}$ & $19.4 \mathrm{a}$ & $73.3 \mathrm{a}$ & $61.7 \mathrm{a}$ \\
FYM (t/ha) applied the previous year & & & & \\
0 & $47.7 \mathrm{a}$ & $20.7 \mathrm{a}$ & $66.5 \mathrm{a}$ & $60.3 \mathrm{a}$ \\
5 & $47.1 \mathrm{a}$ & $20.4 \mathrm{a}$ & $68.0 \mathrm{a}$ & $60.3 \mathrm{a}$ \\
10 & $47.1 \mathrm{a}$ & $18.9 \mathrm{a}$ & $68.2 \mathrm{a}$ & $60.4 \mathrm{a}$ \\
15 & $47.0 \mathrm{a}$ & $20.2 \mathrm{a}$ & $68.3 \mathrm{a}$ & $60.2 \mathrm{a}$ \\
Interaction & & & & \\
V X M & & & & $\mathrm{NS}$ \\
\hline
\end{tabular}

Means followed by the same letter(s) within a treatment group and column are not statistically significant using DMRT $(\mathrm{P}=0.05), \mathrm{NS}=$ Not significant $(\mathrm{P}=0.05), \mathrm{FYM}=$ Farmyard manure, $\mathrm{V}=$ Varieties, $\mathrm{M}=\mathrm{FYM}$ applied the previous year.

Table 6. Effect of rate of previous year applied FYM on the mean pod length $(\mathrm{cm})$ and pod yield (t/ha) of four varieties of cowpea at Samaru during 2005 and 2006 under rainfed condition

\begin{tabular}{|l|l|l|l|l|}
\hline Treatments & Pod length (cm) & \multicolumn{2}{c|}{ Pod yield (t/ha) } \\
\hline & 2005 & 2006 & 2005 & 2006 \\
\hline Varieties & & & & \\
IT93K-452-1 & $13.7 \mathrm{c}$ & $14.0 \mathrm{~b}$ & $2.3 \mathrm{~b}$ & $2.4 \mathrm{~b}$ \\
IT90K-82-2 & $16.2 \mathrm{a}$ & $16.1 \mathrm{a}$ & $2.5 \mathrm{~b}$ & $2.8 \mathrm{~b}$ \\
IT97K-499-35 & $15.7 \mathrm{~b}$ & $16.1 \mathrm{a}$ & $3.4 \mathrm{a}$ & $4.2 \mathrm{a}$ \\
IT96D-757 & $16.1 \mathrm{a}$ & $15.5 \mathrm{a}$ & $1.9 \mathrm{c}$ & $2.4 \mathrm{~b}$ \\
FYM (t/ha) applied the & & & & \\
previous year & & & & \\
0 & $14.2 \mathrm{c}$ & $10.0 \mathrm{c}$ & $2.0 \mathrm{~b}$ & $1.4 \mathrm{~b}$ \\
5 & $15.4 \mathrm{~b}$ & $15.1 \mathrm{~b}$ & $2.5 \mathrm{a}$ & $3.3 \mathrm{a}$ \\
10 & $15.9 \mathrm{a}$ & $18.6 \mathrm{a}$ & $2.8 \mathrm{a}$ & $3.7 \mathrm{a}$ \\
15 & $16.1 \mathrm{a}$ & $18.0 \mathrm{a}$ & $2.8 \mathrm{a}$ & $3.5 \mathrm{a}$ \\
Interaction & & & & \\
Vx M & & & $\mathrm{NS}$ & $\mathrm{NS}$ \\
\hline
\end{tabular}

Means followed by the same letter(s) within a treatment group and column are not statistically significant using DMRT $(\mathrm{P}=0.05), \mathrm{NS}=$ Not significant $(\mathrm{P}=0.05), \mathrm{FYM}=$ Farmyard manure, $\mathrm{V}=$ Varieties, $\mathrm{M}=\mathrm{FYM}$ applied the previous year. 